\title{
Rachel Watts
}

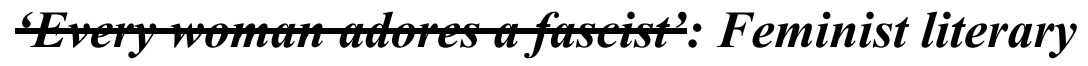 intervention in elegiac writing}

\begin{abstract}
This article is a fictocritical intervention in the patriarchal form of the elegy and a reflection on the expression of grief, anger and subjectivity by women writers. It uses Adrienne Rich's writing on women's self-destruction as a feminist methodological framework to explore two specific ideas. First, how we speak of the dead, which concerns the agency, subjectivity and anger with which we express our remembrance and our grief, and second, literary style and feminist interventions in the elegiac form. Taking a fictocritical approach, the article combines the objective style of the academic mode with a subjective treatment, resulting in a cut-up text that combines analysis and my own reflections. In this, the article is informed by work by Anna Gibbs (1998; 2005) and Ross Watkins (2014). This multivocal approach aims to answer the question: how does the approach to the elegy form employed by Virginia Woolf and Sylvia Plath enable a nuanced representation of grief, mourning and agency, and how can other women writers build on this approach to write to and through each other in the context of a patriarchal literary tradition? Keywords: elegy, feminist literary criticism, fictocriticism
\end{abstract}

\section{Introduction}

In 1974 Adrienne Rich wrote a eulogy for Anne Sexton in which she both reflected on the work of the poet and issued a call to arms: there will be, there must be, no more suicidal women (Rich 1995). She identified four characteristics of women's behaviour in a patriarchal society that lead to selfdestruction: self-trivialisation, misplaced compassion, horizontal hostility and addiction to men's approval. I will use these elements to reflect specifically on work by Virginia Woolf and Sylvia Plath and to assess feminist literary intervention in writing for and about the dead. The work of both writers has been instructive, Woolf for her methodologies for multiple subjectivities in To the Lighthouse (Woolf 2004) and Plath for her urgent and clear voice when speaking about death. Combining these techniques with my own interjections destabilises the patriarchal elegiac form and presents a mourning that is multivocal and empowered. The article also demonstrates the back and forth dialogue of women writers to women writers, both said and unsaid. It hopes to draw attention to the tension between speaking and staying silent and the interactions between women writers and their texts.

Both Woolf and Plath show a willingness to shirk convention when speaking about the dead, as does Rich. Ultimately this article is a reflection on what it means to talk to, or about, the dead with honesty, while maintaining one's own subjectivity and agency. I am deeply interested in the influence of feminist 
writers on other feminist writers and in this article I ask: what does it mean to find inspiration in the work of another? What does it mean to hear a call to arms and to respond?

\title{
Part I: Recreation
}

\section{In which we seek to recreate and praise an idealised version of the dead}

\author{
Bear Sylvia, \\ Every andores a faseist? (Plath 1981: 222)
}

Adrienne Rich's eulogy for Anne Sexton, which appears in On Lies, Secrets and Silence, pays tribute to the poet while mourning not only her loss but the prevalence of suicide among women writers (1995). It is a clear-eyed, incisive treatment of the death of a colleague, but it is also a treatise on women's own self-destructive behaviour: the ways in which their anger becomes turned inward on themselves. It is significant that it was the death of a friend that inspired Rich to make these political points. Her words carry the anger of a woman who sees her friends and colleagues dying, who cannot save them. It is a striking contrast to the words of her essay 'When We Dead Awaken: Writing as Re-Vision' (Rich 1972), which appears in the same collection but was firstpublished three years before Sexton's death: 'the sleepwalkers are coming awake, and for the first time this awakening has a collective reality; it is no longer such a lonely thing to open one's eyes' (Rich 1995: 35).

\section{Iread Virginia's journals too. I read yours. I feel like I know you. \\ But Idon't know you. \\ We have nothing in common. 'Save for the possibly relevant fact that [neither Virginia nor I] had a child.' (Woolf 1984: 61)}

Woolf's To The Lighthouse, read as a post-World War I elegy, may be an unconventional place to start an analysis of the elegy form, but while it is instructive in the elegiac goal of recreating an idealised version of the dead, it can also be read, alongside Rich's eulogy for Sexton, as what Jane Goldman describes as a 'feminist intervention in a narrative of subjectivity' (qtd in Neidel 2016: 13). Woolf's use of multiple focalisers allows the narrative to 'circle' one subject, Mrs Ramsay. After Mrs Ramsay's death, the focalisers must find new patterns of subjectivity, new ways of viewing the world (Neidel 2016: 12-13). The central motif through the text is Lily Briscoe's painting, started at the opening of the novel and only completed in its final pages. It is through its narrative structure, point of view, and Lily's artistic creation that the novel portrays ongoing mourning and the resistance of consolation. It is specifically a female artist, the unmarried Lily, who grapples with the representation, the recreation, of the memory of Mrs Ramsay.

'Every woman adores a fascist'? (Plath 1981: 222)

You're a prism with too many faees, Sylvia. A woman who 'eats men like air'? (247) Howld they bear it?

Rich's identification of self-trivialisation, misplaced compassion and addiction, is reflected in Woolf's treatment of Mrs Ramsay. She is both frustrated by her husband and adoring of him, tempering her thoughts and sharing only those that are palatable with him. Her relationship with Lily, part friendship, part motherhood, part mentorship, ebbs in and out of love and mockery. Lily scoffs at Mrs Ramsay's 'simple certainty' that all women must marry but she also watches Mr Ramsey glance at his wife: 'she thought no woman could worship 
another woman the way he worshipped; they could only seek shelter under the shade' (Woolf 2004: 46, 45).

Hnew a man once. He was made of sardonic grins, and booze, and he was a'brute' (Plath 1981: 222) to his mother, which should tell you something. But he wasn't 'a man in black' (222), or if he has has someone else's man. He was a pet and died with a needle in his vein.

The narrative of the novel slides in and out of the characters' minds, giving it a fluidity of tone that produces a sense both of peace and of restlessness (Raitt 1990: 45-46). Trains of thought are picked up and dropped and resolutions are only ever local, which sets up a problem of resolution throughout the novel as a whole (46). However, Woolf's use of subjectivity allows her to move between close third-person focus and a soaring omniscient focus. In the first section of the novel the living Mrs Ramsay is created and recreated from multiple viewpoints, within a microcosm of the 'horror' and 'alliance' of family life (Woolf 2004: 68). The final scenes seem out of focus and, while the lighthouse is reached, any resolution is only temporary. Woolf herself writes in her diary that she wants Mr Ramsay to reach the lighthouse at the end, but then asks what becomes of Lily and her painting? (Woolf 1954: 98).

Fonly met my grandfather onee, as an adtlt, That Man, that aggressor. But by then he was old and dying from eigarettes and aleohol and years. He sat outside smoking, shrunken in a way that made me think of Saddam Hussein in his underwear.

'Could I do it in a parenthesis?' Woolf asked in her journal, grappling with the novel's conclusion. 'So that one had the sense of reading the two things at the same time?' (Woolf 1954: 98).

Iam a teenager. I am in bed on the top floor of my father's house. It is late, my eyes are stopped up with darkness and 'the light [from my] mind'(Plath 1981: 1). The trains have stopped vibrating the bones of the house, so I ean hear my dad talking to his wife. His voice jumps four flights of stairs like 'a miracle!'(246)

'Youknow she won't be a journalist.'

'She'll have tots of babies.'

'She's only interested in little things.'

And it is the sense of 'two things at the same time' (Woolf 1954: 98) that characterises the novel, as well as this article, and finally leads to a lack of closure. The artist in Lily, and by extension in Woolf, offers an awareness of the passage of time, of loss that cannot be assuaged by compensatory art, but that must be carried into the present as ongoing relationship with the past

(Clewell 2004: 22).

Isn't all grief incomplete, Sylvia?

Boesn't it haunt you, always?

Idreamt my father stod outside my house, his baek to me. As he turned, gtaeially, I rushed to the door. I eouldn't let his dead eyes see me. I eouldn't see his dead eyes. I loeke the door on him and I never saw him again.

\section{Part II: Lament}

In which we mourn and question 
To The Lighthouse opens with an answer: "YYes of course, if it is fine tomorrow," said Mrs Ramsay' (Woolf 2004: 3) and, as Suzanne Raitt identifies, the rhythm of the novel is one of question and response, and hiatus (1990: 44). Similarly, the questions that begin the book's third section are characteristic of the elegiac form: 'What does it mean then, what can it all mean?' (Woolf 2004: 139).

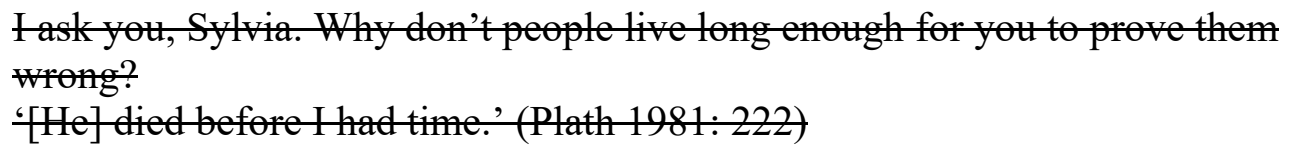

The ebb and flow between adoration of the patriarchal figure, and frustration with it, between love and hostility between women, between practical accomplishments and self-trivialisation, are what make the relationships in the novel striking. Not least for the shifting subjectivity with which they are portrayed - Woolf's triumph in this novel. However, these relationships depart from Rich's thesis, which identifies women's self-destruction as the result of self-trivialisation, horizontal hostility and addiction to the attention of men. In Woolf's novel the aggression comes from forces external. Death comes out of history and seems to come from all sides: 'rather suddenly', 'in an illness connected with childbirth' and 'instantaneous' (Woolf 2004: 122, 126, 127). The deaths of Mrs Ramsay, Prue Ramsay and Andrew Ramsay, even the war, are parenthetical to the onslaught of nature, of time. Woolf's parenthetical approach is a stylistic unsettling of subjectivity employed throughout her work. She dismissed what Eric Auerbach described as the 'great exterior turning points' (qtd in Delorey 1996: 105) of her stories as 'masculinist', instead using parentheses to offer a transient subjectivity and to open up a space in which to express truths that were perhaps unpresentable (Delorey 1996). In To the Lighthouse, written in an era defined by war, the elements are uncaring. $\mathrm{Mr}$ Ramsay reaches for his wife and his hands come back empty.

Think of you often Sylvia, perhaps more so beeattse you're gone. You and my father.

After Mrs Ramsay's death the number of focalisers is reduced and instead of having a fluid, multi-dimensional perspective, all gazes are aligned along one plane - between the house and the lighthouse (Raitt 1990: 100). The majority of the last section is also seen through Lily's eyes - as opposed to the majority of the first section being viewed through Mrs Ramsay's subjectivity. Lily, as a painter, is recreating a way of seeing Mrs Ramsay and by extension the mother and child, and womanhood itself. This recreation is fleeting and, like the human relationships it depicts, is in a state of constant repair (Leaska 1970).

Would Virginia, would $I$, would you consider us barren women? Bid children 'humanise' you? (Plath 2000: 519)

In When We Dead Awaken, first published in 1971, Rich identifies the 'selfdestructiveness of male dominated society' that she will return to in her piece on Sexton three years later (1995: 35). Before the death of her friend her writing on such self-destruction lacks the same bitter urgency. In reading Rich's 1974 eulogy, one gets the impression that opening one's eyes has become lonelier than anticipated.

Heleneh my jaw when I write. My teeth hurt.

teannot get 'through' to you. (Plath 1981: 222)

Jahan Ramazani claims that when self-censorship or the idealising conventions of the tradition take hold of the memory of the deceased, hostility is driven inward (qtd in Clewell 2004: 205). Turning hostility inward is what Rich rages 
against in her eulogy following Sexton's death, and Ramazani identifes 'prohibitions against female anger' as supporting such a tendency (Ramazani 1994: 266). Further, when it comes to hostility it is the devices in Plath's work that allow the elegy to take a new vitriolic turn. Ramazani claims Plath's later work freed women poets, including Sexton and Rich, from the 'prostrate role dictated by literary and gender codes to the female mourner' (1994: 263). In examining agency and subjectivity in mourning, Plath's unique first-person voice and rejection of convention when talking about death, dying and the dead adds energy to the study of elegy and women's expression.

In 'Little Fugue', written in 1962 and published in Ariel in 1965, Plath describes a subjectivity that is eyeless, blind, deaf, colourless - a direct contrast to the elegiac tradition of conversing with the dead. She writes: 'So the deaf and dumb / Signal the blind, and are ignored' (Plath 1981: 187). This poem is reminiscent of Woolf's approach in the Time Passes section of To The Lighthouse: 'the trees standing there, and the flowers standing there, looking before them, looking up, yet beholding nothing, eyeless and so terrible' (2004: 129). It is like the initial shock of loss, the first days of mourning and the realisation that as time goes by the memories of the dead grow more disjointed. 'Little Fugue' is a portrait in black and white, with the two meanings of the word 'fugue' each taking a role. So the poem is both a musical piece and an eyeless, lost-to-the-self mist (Bundtzen 1983: 191).

Who am I? I have been talking bout [Virginia, Sylvia, Lily and Paddy]. AmI all of them? Am I one and distinet? I do not know.'(Woolf 1992: 222)

This grief will not be consoled with dialogue. Plath 'sees' her father's voice and, far from consoling, it is 'gothic and barbarous' (1981: 188). Does she see through what he says? Plath claims to be 'lame in the memory' (188) as she enacts the elegiac questioning, the search for answers. This search is represented by that sensory deprivation, a white, cloudy sky, a white eye, 'great silence of another order' and the bright pops of colour that the poem contrasts: 'They colour my sleep / Red, mottled, like cut necks' (35) and 'I remember a blue eye / A briefcase of tangerines' (188). The poem ends with 'Death opened, like a black tree, blackly' (188) before returning to the white motif. Plath's mourning here isn't consolatory. It is an ignorance, to survive is to be blank, to be 'lame in the memory'. What is lost is the ability to see clearly, for fear of what might be there, punctuated by expressions of guilt. Plath reaches for the memory of her father, and finding only hyper-real snippets, turns that gaze inward - blaming and simultaneously excusing herself.

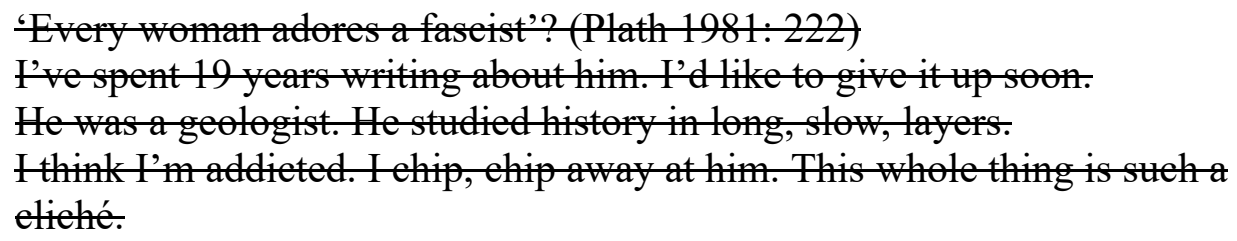
eliché.

The recreation of the deceased takes a more outwardly violent form in Plath's late 1962 poem 'Daddy', also published in Ariel in 1965. This elegiac parody turns the form into an attack in which Plath takes on the role of both victim and collaborator using vividly brutal Holocaust imagery. However, a nuanced elegiac reading of the poem is offered by R Clifton Spargo, who suggests the Nazi imagery is not the metaphor, but the 'Daddy' character is. Starting with the loss of the father, attempting to 'recover you', represents a reflection on the unresolved work of mourning. In the following stanzas the loss is broadened to take the work of mourning in a broader collective and historical sense (Spargo 2004: 267). 
'Daddy' is hugely unsettling. It carries the rhythms and rhymes of childhood, depicting the speaker as an impotent, enraged child - parallel to Rich's identification of the habit of self-trivialisation. She adores and abhors the Daddy character, so much so that she would die to 'get back' to him. She is angry that he died, angry at his legacy left to her and angry at a history in which all the world is complicit.

I'm angry too Sylvia. The world makes me angry.

\section{Part III: Consolation}

\section{In which, instead of pursuing reassurance, we take on responsibility and give voice to legitimate anger}

At the heart of the elegy is a paradox: the inability to forget and the desire as well as pain of remembering (MacDonald 2005: 14-15). The paradox creates resistance to easy solutions and generates tension. It also gives rise to the questioning in the mourner that is a familiar part of the traditional elegy (Sacks 1985: 22). But in modern elegy, consolation isn't sought, instead it is often actively avoided, with a sense of the ethical remembrance that would not seek to lay the dead to rest, nor to introject them in the Freudian sense, but to carry the dead into the future as a separate and enduring other (Rae 2007: 17). This is an ethics of mourning that draws energy from the work of Jacques Derrida when he says of the gaze of Roland Barthes: 'it is within us but it is not ours' (Derrida 2001: 44). In the hands of a feminist and poet like Rich, this approach demands not only open ended, unresolved mourning, but also a mourning that can be wielded. Can mourning be angry? Can mourning inspire?

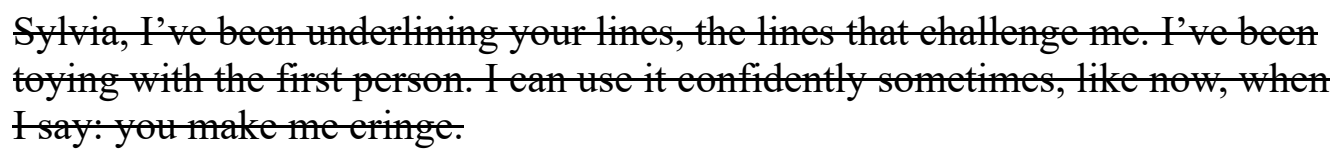
toying with the first person. I ean use it eonfidently sometimes, like now, when Isay: youmake me eringe.

Tannis MacDonald identifies revelation as being the focus of elegy, drawing on the work of Abbie Findlay Potts. She offers anagnorisis, a term taken from Aristotle's Poetics, as an elegy's defining revelation or discovery 'through the display of feelings aroused by memory, by reason or inference, fictitiously by false reference or intended deceit or - best of all - out of the nature of previous events or antecedent discoveries' (Potts qtd in MacDonald 2005: 2). It is MacDonald's argument that the previous events include the tensions and social expectations of father-daughter kinship, and the need to redefine female filial piety (MacDonald 2005: 15).

According to Spargo's reading, 'Daddy' represents a deliberate trivialising of the past, the unspeakable history is assessed in caricature, as 'a man in black with a Meinkampf look' (Plath 1981: 224). The Man also surfaces in Rich's essays. In When We Dead Awaken she writes that 'the Man' in women's writing is a fascination and terror, 'and the source of the fascination and terror is, simply, Man's power - to dominate, tyrannise, choose or reject the woman' (1995: 36). 
In 'Daddy', the speaker mutters the poem's final line, as though through her teeth: 'Daddy, daddy, you bastard, I'm through' (Plath 1981: 224). Plath makes full use of the double meaning of the word 'through' (stake through the heart/finished) to reveal a mourning that is destructive and ambiguous (Nance \& Jones 1984: 128). The exorcism of the image she has created of an oppressive father figure leaves her depleted (1984: 128) and even when she cuts out those memories there will be an empty space where they once were. For Woolf, there is a similar empty space occupied by a parenthetical approach to loss on both a personal level, Mrs Ramsay, and on a historical scale, World War I. Woolf's multiple focalisers encircle this loss, a hollow core, that is too great to describe. Lily's painting can never quite represent the loss fully.

Ithink of sitting at my grandfather's funeral. They called him loving man, family man, musieal man. They didn't know I wasn't there to lay a wreath at the feet of a statne that looked like him. They didn't know I was there to tear it down.

If Woolf's To The Lighthouse can be read as a broader elegy for the historical break occasioned by World War I, Plath's 'Daddy' can be read in reference to both an oppressive patriarchy and a larger sense of collective responsibility for the Holocaust. And Plath makes it clear that it isn't just her, it is all women - a double thrust parallel to Rich's horizontal hostility and addiction to men's approval. In those memorable lines, 'every woman adores a fascist', she almost sneers at the addiction to men's approval that Rich identifies in her 1974 eulogy for Sexton. But it is complicated by her appropriation of devastation on a scale other artists rarely attempt.

\section{Sylvia, I want to tear them down.}

Rich's argument is that the place women hold in society forces them to enact anger in ways that are self-destructive. And she makes the case that women are active in maintaining this position. For Plath, the unresolved mourning and sense of responsibility leads to the self-destructive urge: the urge to 'get back, back, back' (Plath 1981: 224). The speaker both adores and is terrified of the effigy she has created. Similarly, she both adores and is terrified of the model she creates, her husband, whom she also symbolically kills. She is in thrall to a violence, a place in a horrific history, and she cannot let it go. To recount Simone De Beauvoir's claim:

To decline to be the Other, to refuse to be a party to the deal this would be for women to renounce all the advantages conferred upon them by their alliance with the superior caste... When man makes of women the Other, he may, then, expect her to manifest deep-seated tendencies toward complicity. (De Beauvoir 1989: xxvii)

\section{Heep thinking of Drisy Cousens. The way she's somehow so good to hate. That's horizental hostility right there. But $I$ bet she'd adore a faseist.}

Much of Plath's work identifies a rupture at the juncture of her experience as a woman, as a mother, and as a poet. Her 1963 poem 'Kindness', published in Ariel, draws a contrast between the 'Angel in the house' and the 'blood jet' of poetry (Plath 1981: 270): "When Kindness hands her "two children, two roses" an insoluble choice is offered: Your children or your poetry' (Bundtzen 1983: 6). Lynda Bundtzen identifies Plath's recurrent death themes as being uniquely tied to her artistic identity as a woman and the challenges she faced recreating her own self-image after the end of her marriage. At times, her self-destruction and resurrection are successful, 'Lady Lazarus' being an example. And at times 
death seems attractive as an act of defiance or self-control. If self-destruction was the only defiance that a woman could wield, Rich's thesis is supported by Plath's work. However, in 'Daddy' her engagement in the world of the oppressor is to assist in his recreation and his destruction, as well as his victim. Her mourning resists the tendency to turn the aggression on the self, Ramanazi identifies, instead wielding it against the dead (qtd in Clewell 2004: 205).

\section{But Sylvia, then you had to publish. Eviseerating, vibrating, lies and honesty each wearing the same arnival mask. Is that what killed you?}

Perhaps the ability to express anger is crucial in finding new ways of speaking about the dead with agency and subjectivity, guided by Rich's thesis on women's self-destruction. Rich claimed that self-destruction was based on women's complicity, their misplaced compassion, their hostility towards each other and their self-trivialisation. Is it the expression of righteous anger, within a feminist framework of mourning and elegiac writing, that will help us to resist self-destruction? Is it by wielding anger that, in grief, we resist being taken by death too - metaphorically or literally? Rich herself identified Woolf's own anger in When We Dead Awaken. She describes Woolf's A Room of One's Own, first published in 1929, as carrying 'the tone of a woman almost in touch with her anger, who is determined not to appear angry, who is willing herself to be calm, detached and even charming in a roomful of men' (1995: 37).

To the reader Plath's anger appears to have emerged from nowhere, but it is already there smouldering, in the work of women writers over centuries something that Woolf identified in Charlotte Bronte's work: 'we feel the influence of fear in [Mr Rochester], just as we constantly feel an acidity which is the result of oppression, a buried suffering smouldering beneath [Bronte's] passion' (Woolf 1984: 68). It seems the 'Man in Black' has stalked the pages of women writers for centuries. In some of Plath's more vehement work the smouldering catches alight.

Or, Sylvia, was it your work that kept you alive?

'If only [you] knew how high [you] could set [your] goals'. (Plath 2000: 151)

When writing a study of the elegiac work of Woolf and Plath, it cannot escape mention that they each caused their own deaths. Despite this being shared by the pair, Plath's frankness about the dead, and about death itself, singles her out. Even while indentifying a similar tone in Plath's last poems as in Woolf's last diary entries, Elizabeth Hardwick notes their approach to their own deaths, and to death as a concept, is fundamentally different (Hardwick 1985: 106). On the day of her death Woolf expresses only depression, apology and gratitude. While Plath's last journal entries were destroyed, in her work death is an assertion of power, a performance, a rebirth or a leap of faith. Poems in which her self-destruction and regeneration are successful have 'an inescapable bouyancy, a feeling of weightlessness, of sublimation into fire and air' (Bundtzen 1983: 35). This is connected to her artistic expression. Death, in its own way, is a risk caught up in her practice as a writer. The risks for women in exercising artistic expression are also of interest toWoolf - 'one slip' means death for Jane Austen or 'instant dismemberment by wild horses' for herself (Marcus 1981: 12).

\section{Sylvia. You killed you. \\ Was your wotk not enough, in the end? Or was it too mueh?}

Plath and Woolf write as women keenly aware of what Sandra M Gilbert and Susan Gubar identify as an element of trespass, which they describe as the 'anxiety of authorship' (qtd in Bundtzen 1983: 114). In 1976, Suzanne Juhasz 
identified a similar dichotomy in Naked and Fiery Forms: Modern American Poetry by Women, a New Tradition: 'If the woman poet "writes like a man," she denies her own experience; if she writes as a woman, her subject matter is trivial' (qtd in Bundtzen 1983: 114). Both Woolf and Plath expressed trepidation in their journals about how to navigate their roles as women writers and to some extent Plath was bouyed by the example Woolf had set. Woolf too sought community in her women writer forebears and wrote of struggling to find 'a sentence that could hold its own against the male flood' (Marcus 1981: 20) but also depicted Shakespeare's sister as killing herself because of her restriction to a marriage she did not choose and the denial of her talents (62). Plath's world presented her with the choice of being a perfect homemaker or being the phoenix-poet woman who can 'eat men like air' (Plath 1981: 247) and instead she strived to be both. Similarly, not only did she write elegies, anti-elegies and self-elegies, she also in some ways eulogised the elegy - in 'Lady Lazarus' describing dying as not only an art but also a trade (Plath 1981). Thus Plath implies that the trade of the confessional poet, performative as it is, carried the price of pain, self-exposure and suicide (Ramazani 1994: 286). The centrality of her experience of womanhood in her writing suggests that the price of confession is greater, and potentially more deadly, for women.

\section{It's all the same thing. This risk. This 'miracle!'(Plath 1981: 55)}

In assessing how writers manipulate the conventions of the elegy, the work of Woolf and Plath provides models for fractured subjectivity, anger and reclamation. Their work also models dialogic encounters between writers and early forms of fictocritical reflection. Rich herself described the act of looking back, 'of entering a new text from a new critcical direction', as being, for women, 'an act of survival' (Rich 1995: 35). It was from that starting point that my own work developed into an investigation of feminist literary intervention into the patriarchal elegiac form, with specific regard to Rich's eulogy for Anne Sexton. I continue to question what it means to remember and speak of the dead as a conflicted, cut-up remembrance, multivocal and multifaceted. This multiplicity of views informs a literary approach to breaking the 'rules' with regard to speaking of the dead, and one I am interested to apply to my own fictocritical work.

The methodological approach to subjectivity employed by Woolf, alongside the harnessing of anger in the face of death I have described in the poetry of Plath provide two mutally compatible ways to speak to and of the dead without adhering to established convention. Both writers use shifting focaslisations, via a fluid third person and a shifting first person, to direct the reader's eye and ear around a presence/absence. But there is something else in their work that runs deeper, that both women were striving to express, to uncover. The tension between the spoken and the unspoken, the vilification of women who say too much, or who say anything at all, rings through in their work and it is a crucial point of interest in this article. Ultimately, their work and their biographies fit with Rich's thesis on the self-destructive habits of women. But to take it one step further, I argue that the combination of their approaches creates a wholly new, disorienting, multifaceted expression that might resist self-destruction in favour of nuanced anger and self-empowerment. The lives and work of these writers also identify risks inherent in women writing against convention, especially when writing about the dead. These inextricable links between the personal and the creative have guided the cut-up style of this article, weaving analysis with reflection into a multivocal, at times engraged, enactment of both writers' approaches. 
While both women were very much constrained by their times, Plath and Woolf were women concerned with how to be a woman, and how to grieve, in a literary tradition. They searched, and found, and searched again for their own literary heroes and granted themselves permission to begin, to mourn, to fail, and to continue.

\section{PS}

\section{I'm alrealy thinking about the next story. It will be about a woman whose-story} never ends.

\section{Works cited}

Bundtzen, LK 1983 Plath's Incarnations: Woman and the Creative Process, University of Michigan Press, Ann Arbor return to text

Clewell, T 2004 'Consolation Refused: Virginia Woolf, The Great War and Modernist Mourning', Modern Fiction Studies 50, 1: 197-223 return to text

De Beauvoir, S 1989 The Second Sex, Vintage Books, New York return to text

Delorey, D 1996 'Parsing the Female Sentence: The Paradox of Containment in Virginia Woolf's Narratives', in K Mezei (ed) Ambiguous Discourse: Feminist Narratology and British Women Writers, The University of North Carolina Press, Chapel Hill NC: 93-108 return to text

Derrida, J 2001 The Work of Mourning, PA Brault \& M Naas (eds), The University of Chicago Press, Chicago return to text

Gibbs, A 1998 'Afterword', in H Kerr \& A Nettelbeck (eds) The Space Between: Australian Women Writing Fictocriticism, University of Western Australia Press, Nedlands: 45-52 return to text

Gibbs, A 2005 'Fictocriticism, Affect, Mimesis: Engendering Difference', TEXT: Journal of Writing and Writing Courses 9, 1: http://www.textjournal.com.au/april05/gibbs.htm (accessed 3 April 2017) return to text

Hardwick, E 1985 'On Sylvia Plath', in P Alexander (ed) Ariel Ascending, Harper \& Row, New York: 100-115 return to text

Leaska, MA 1970 Virginia Woolf's To The Lighthouse: A Study in Critical Method, Columbia University Press, New York return to text

MacDonald, T 2005 'The Daughter's Consolation: Melancholia and Subjectivity in Canadian Women's Paternal Elegies', University of Victoria (Canada), ProQuest Dissertations Publishing (accessed 15 March 2017) return to text

Marcus, J 1981 New Feminist Essays on Virginia Woolf, University of Nebraska Press, Lincoln NE return to text

Nance, GA \& JP Jones 1984 'Doing Away with Daddy: Exorcism and Sympathetic Magic in Plath's Poetry', in L Wagner-Martin (ed) Critical Essays on Sylvia Plath, G K Hall \& Company, Boston: 124-130 return to text

Neidel, AR 2016 'Expanding feminist narratology: A study on the narrative strategies of Virginia Woolf, Gertrude Stein, and Nella Larsen', ProQuest Dissertations \& Theses Global. Order No. 10164908: http://search.proquest.com.dbgw.lis.curtin.edu.au/docview/1845017079 (accessed April 15 2019) return to text

Plath, S 1981 Collected Poems, Faber \& Faber, London return to text

Plath, S 2000 The Unabridged Journals of Sylvia Plath, Anchor Books, New York

Rae, P 2007 'Introduction: Modernist Mourning', in P Rae (ed) Modernism and Mourning, Bucknell University Press, Lewisburg: 13-49 return to text 
Raitt, S 1990 Virginia Woolf's To The Lighthouse, St Martin's Press, New York return to text

Ramazani, J 2007 'Afterword: "When There are So Many We Shall Have To Mourn", in P Rae (ed) Modernism and Mourning, Bucknell University Press, Lewisburg: 286-295

Ramazani, J 1994 Poetry of Mourning, University of Chicago Press, Chicago return to text

Rich, A 1995 'Anne Sexton 1928-1974', in On Lies, Secrets and Silence: Selected Prose 19661978, W W Norton \& Company, New York: 121-124 return to text

Rich, A 1972 'When We Dead Awaken: Writing as Re-Vision', College English 34, 1: 18-30 return to text

Sacks, PM 1985 The English Elegy: Studies in the Genre from Spenser to Yeats, The Johns Hopkins University Press, Baltimore return to text

Spargo, RC 2004 The Ethics of Mourning: Grief and Responsibility in Elegiac Literature, The Johns Hopkins University Press, Baltimore return to text

Watkins, R 2014 'Bodies in boxes: a fictocritical search for the writing process', in N Krauth, DL Brien, R Watkins \& A Lawrence (eds) Creative Writing as Research III, TEXT Special Issue 27: http://www.textjournal.com.au/speciss/issue27/Watkins.pdf (accessed 3 April 2017) return to text

Woolf, V 1984 A Room of One's Own and Three Guineas, Chatto \& Windus The Hogarth Press, London return to text

Woolf, V 1954 A Writer's Diary, Harcourt, New York return to text

Woolf, V 1992 The Waves, Penguin Books, London

Woolf, V 2004 To the Lighthouse, Vintage, London return to text

Rachel Watts has a Master's Degree in Media and Communication (Creative Practice) from Curtin University and teaches in the university enabling program at Murdoch University. Her work focuses on creative practice, subjectivity and grief. She has had fiction and essays published by Westerly, Island and Tincture Journal among others. This article was part of her Master's exegesis at Curtin University.

\section{TEXT}

Vol 23 No 1 April 2019

http://www.textjournal.com.au

General Editor: Nigel Krauth. Editors: Julienne van Loon \& Ross

Watkins

text@textjournal.com.au 